
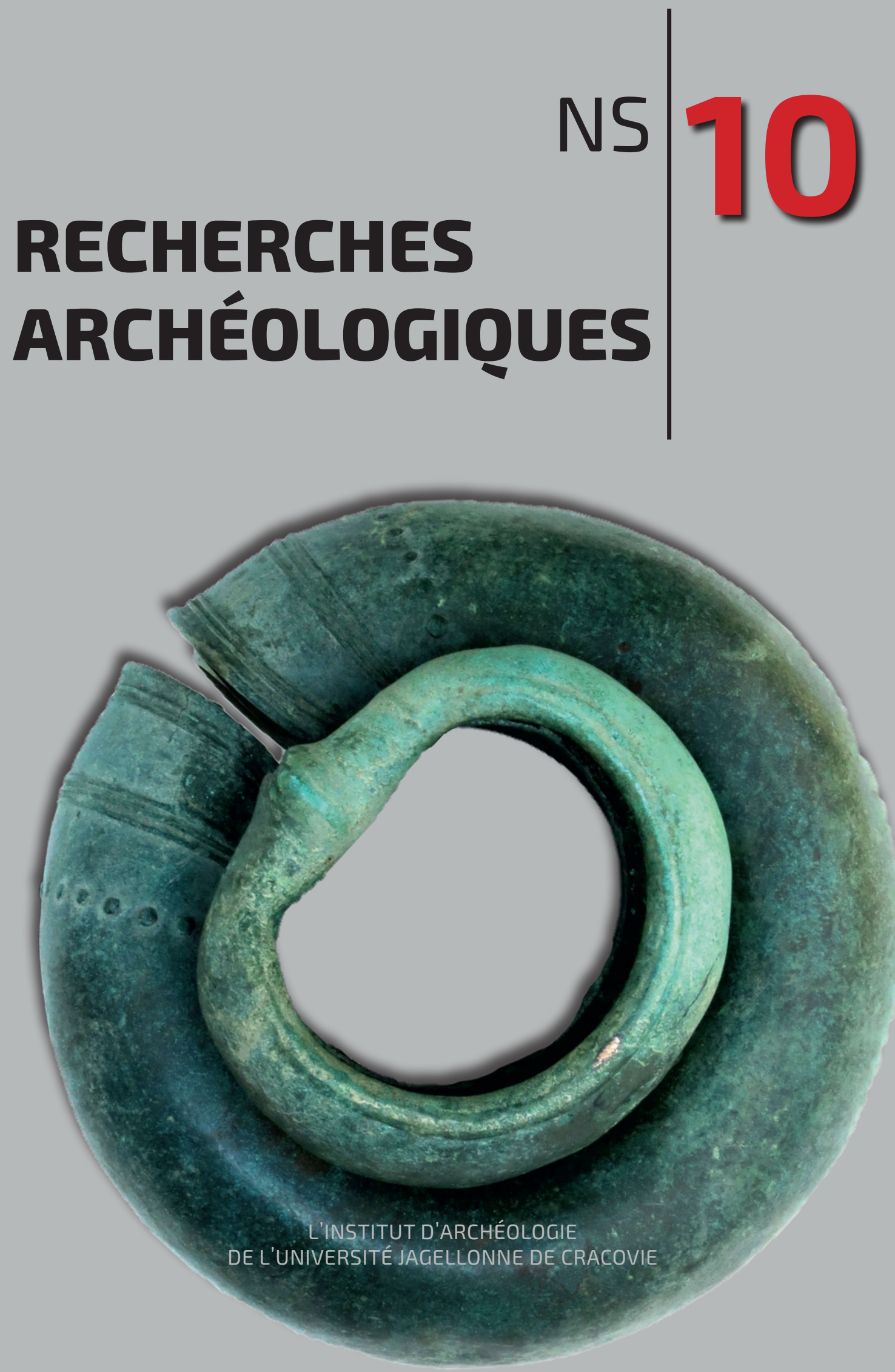
RECHERCHES ARCHÉOLOGIQUES NOUVELLE SERIE 

L'INSTITUT D'ARCHÉOLOGIE

DE L'UNIVERSITÉ JAGELLONNE DE CRACOVIE

RECHERCHES ARCHÉOLOGIQUES

NOUVELLE SERIE 10

(2018)

KRAKÓW 2019 
(C) Copyright by Institute of Archaeology of the Jagiellonian University, Kraków 2019

\author{
RÉDACTEUR EN CHEF \\ Przemysław Nocuń \\ SÉCRETAIRE DE LA RÉDACTION \\ Michał Kasiński \\ COMITÉ DE RÉDACTION
}

Jan Chochorowski, Krzysztof Ciałowicz, Ulla Lund Hansen, Renata Madyda-Legutko, Vjacheslav I. Molodin, Ewdoksia Papuci-Władyka, Jacek Poleski, Pál Raczky, Paweł Valde-Nowak

RÉDACTEURS DU SUJET

Wojciech Blajer, Janusz Ostrowski, Krzysztof Sobczyk, Joachim Śliwa

COMITÉ DE LECTURE

Dagmara Adamska, Justyna Baron, Małgorzata Chorowska, Adam Cieśliński, Katarzyna Czarnecka, Przemysław Dulęba, Jan Jílek, Maciej Kaczmarek, Andrzej Maciałowicz, Marcin Maciejewski, Kyrilo Myzgin, Marcin S. Przybyła, Marzena Przybyła, Tomasz Ratajczak, Judyta Rodzińska-Nowak, Sławomir Sprawski, Michał Wojenka

ÉDITEURS DE LANGUE

Piotr Godlewski, Keith Horechka

MAQUETTE DE COUVERTURE, MISE EN PAGES

Wydawnictwo i Pracownia Archeologiczna PROFIL-ARCHEO Magdalena Dzięgielewska

ADRESSE DE LA RÉDACTION

Instytut Archeologii Uniwersytetu Jagiellońskiego, ul. Gołębia 11, PL 31-007 Kraków

www.farkha.nazwa.pl/RechACrac/

www.archeo.uj.edu.pl/RechACrac/

La version originale des Recherches Archéologique Nouvelle Serie est la version papier

"Recherches Archéologiques Nouvelle Serie" est régulièrement sur la liste dans The Central European Journal of Social Sciences and Humanities

Podniesienie poziomu umiędzynarodowienia tomów nr 9 i 10 czasopisma "Recherches Archéologiques, Nouvelle Serie" - zadanie finansowane w ramach umowy nr 606/P-DUN/2018 ze środków Ministerstwa Nauki i Szkol-

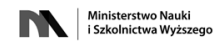
nictwa Wyższego przeznaczonych na działalność upowszechniającą naukę

ISSN 0137-3285

Publikacja finansowana przez Uniwersytet Jagielloński

Cette publication est financée par l'Université Jagellonne 


\section{CONTENU}

\section{ÉTUDES}

Wojciech Blajer: Some remarks on socketed axes of the Passau type

Karol Dzięgielewski, Anna Longa, Jerzy Langer, Magdalena Moskal-del Hoyo: Contextualisation of the Early Iron Age hoard of bronze objects discovered in Gdynia-Karwiny, site 1

Przemysław Dulęba: New data for studies on settlement and economy of the La Tène culture in Lower Silesia

Przemysław Dulęba: La Tène culture in Silesia. Remarks on the state of research and new cognitive perspectives

Krzysztof Michalczewski, Jan Bulas: Flat scrapers made of bone from Pre-Roman and Roman Period on the Polish Lands

Dariusz Niemiec: $13^{\text {th }}$-century fortifications of Kraków

Jarosław Bodzek, Kamil Kopij, Szymon Jellonek, Barbara Zając: Studies on Roman coin finds from the Central European Barbaricum in the Institute of Archaeology of the Jagiellonian University - an overview

\section{RAPPORTS}

Michał Kasiński, Jan Bulas, Magdalena Okońska: A newly discovered Przeworsk culture settlement and burial ground from the Late Pre-Roman and Roman period at Bejsce, Dist. Kazimierza Wielka - preliminary results of field-walking survey and rescue excavations

Joanna Zagórska-Telega, Jacel Pikulski, Anita Szczepanek: Archaeological excavations of multicultural site 1 at Michałowice, Commune Czarnocin, in seasons 2013-2014

Paulina Kowalczyk-Matys: Figural tile from the first half of the $16^{\text {th }}$ century with a young man from Jagiellońska Street in Kraków 
Michał Kasiński ${ }^{1}$, Jan Bulas², Magdalena Okońska ${ }^{3}$

\title{
A newly discovered Przeworsk culture settlement and burial ground from the Late Pre-Roman and Roman period at Bejsce, Dist. Kazimierza Wielka - preliminary results of field-walking survey and rescue excavation
}

\begin{abstract}
The article presents preliminary results of surface survey conducted under the leadership of the authors of this paper in spring of 2019 on multicultural complex of sites occupying a hill located in south-western part of Bejsce, Dist. Kazimierza Wielka. Among discovered finds the most numerous were the pottery fragments attributed to the Przeworsk culture dated to the Late Pre-Roman period, Roman period and early phase of Migration period. Settlement or possibly complex of settlements of the Przeworsk culture covered the southern part of the surveyed terrain form, while approximately $300 \mathrm{~m}$ to the north from the boundary of the settlement, remains of a badly damaged necropolis, dated to Late Pre-Roman and Early Roman Period were found. Because in case of one grave, situated immediately by a deep balk, ploughing uncovered a part of its fill in situ, to prevent the ongoing destruction of the grave, a decision was made to perform rescue excavations in this place.
\end{abstract}

Keywords: Przeworsk culture, settlement, burial ground, Late Pre-Roman Period, Roman Period

\section{Introduction}

The Przeworsk culture settlement and burial ground at Bejsce, Dist. Kazimierze Wielka discussed in this paper, dated to the Late Pre-Roman Period and Roman period, is part of a multicultural complex of sites occupying a hill overlooking the Nidzica River valley, situated in the south-western part of the village. From the south and west, the hill is confined by the valley of the Nidzica, while from the north and east the slopes fall gently towards the valleys of two nameless watercourses being left tributaries of the mentioned river. The hill plateau rises approx. $13 \mathrm{~m}$ above the floodplain bottom, totals approx. 80 ha in area, and is currently intensively used for agriculture. Only in the north and east of the plateau are there houses and household buildings forming two hamlets belonging to Bejsce: Łabędź and Pasternik (Fig. 1).

\footnotetext{
1 Institute of Archaeology, Jagiellonian University in Kraków, 11 Gołębia St., 31-007 Kraków, Poland, michal.kasinski@uj.edu.pl

2 Institute of Archaeology, Jagiellonian University in Kraków, 11 Gołębia St., 31-007 Kraków, Poland, bulas.jan@gmail.com

3 Institute of Archaeology, Jagiellonian University in Kraków, 11 Gołębia St., 31-007 Kraków, Poland, lena.okonska@wp.pl
} 


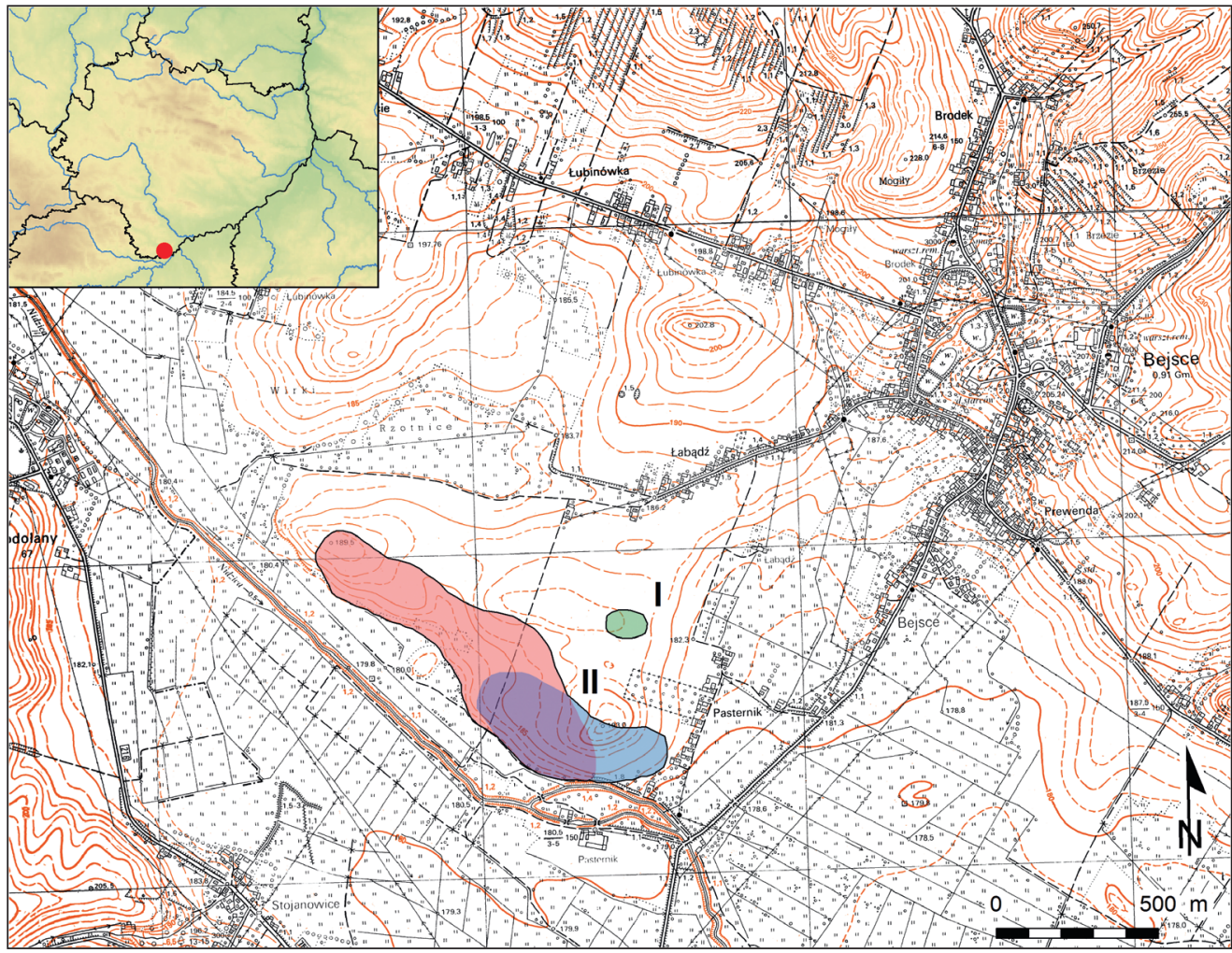

Fig. 1. Locations of sites dated to the period of the Przeworsk culture development at Bejsce; I - cemetery from the Late Pre-Roman and Early Roman period; II - Przeworsk culture settlement (blue colour marks approximate distribution of materials dated to the Late Pre-Roman and Early Roman period, red colour marks approximate distribution of materials dated to the Younger and Late Roman periods)

The mentioned complex of sites lies in a micro-region situated in the eastern part of the Proszowice Plateau - a geographic region characterised by high coverage of fertile soils, mostly formed on loess (Kondracki 1965, 403). Moreover, the location is favourable from the point of view of communication - it is situated between the Nida and Nidzica, with both rivers flowing into the Vistula River relatively close to the site. Also not far from there, the Dunajec River flows into the Vistula from the south. Thus, this is where three considerable tributaries of the Vistula River meet, all of which were significant communication routes in various periods in prehistory. Both these factors favoured prehistoric occupation. Its beginnings can be traced back to the Neolithic times (Kruk 1980; Kulczycka-Leciejewiczowa 1987), and particularly abundant traces are known from the period of the Przeworsk culture development (Kaczanowski, Madyda-Legutko 1986; Dobrzańska 1995; Garbacz 2009). The earliest among the latter date to the middle and late sections of the younger Late Pre-Roman Period and come from cemeteries at Stradów, Comm. Czarnocin (Gajewski, Woźniak 2000), Pełczyska, Comm. Złota (Rudnicki 1996; Kontny, Rudnicki 2002), and Michałowice, Comm. Czarnocin (Zagórska-Telega, Pikulski, Szczepanek 2011; Zagórska-Telega, Pikulski, Bulas 2012). Also with the same period one should link the beginnings of a settlement at Jakuszowice, Comm. Kazimierza Wielka, which continued to function in the Early Migration period (Godłowski 1986; 1991; Rodzińska-Nowak 
2006; Kaczanowski, Rodzińska-Nowak 2008), and a settlement at Zagórzyce, Comm. Kazimierza Wielka (Grygiel, Pikulski, Trojan 2009a; 2009b).

Aerial and satellite imaging, including photographs available through the Head Office of Geodesy and Cartography, revealed numerous vegetation anomalies within the discussed complex of sites, confirming intensive prehistoric occupation of the mentioned terrain form (Fig. 2). The large area where the anomalies occurred and their diversity indicated that we are dealing here with a series of overlapping, heterochronous phenomena. It should be noted that some of the observed vegetation anomalies, which were close to rectangles in plan, suggested the presence of sunken-floor buildings, characteristic of Przeworsk culture settlements. In order to verify these observations, and to determine the chronological and spatial frameworks of particular sites forming the complex, a decision was made to undertake surface surveys in this area, which were carried out under the leadership of the authors of this paper in spring of 2019.

Numerous fragments of ceramic vessels were found at the surface of the discussed complex of sites, most of which were recorded along the southern slope of the hill. These were primarily potsherds attributable to the Przeworsk culture, with fewer finds from other periods, from the Neolithic up to post-medieval times. The earliest finds linked with the Przeworsk culture date to the Late Pre-Roman and the Early Roman period, and they concentrate mainly in the southeastern part of the hill. Moreover, many traces of occupation dated to the Younger and Late Roman periods were recorded, with concentration in the central and western parts of the southern slope. It needs to be mentioned here that the surveys performed to date have not encompassed the whole of the discussed terrain form - fragments covered with vegetation at the moment of research have been omitted. Furthermore, the available data are insufficient for concluding to what degree the recorded picture is affected by geomorphology, dynamics of slope processes, and other post-depositional processes. Therefore, the extent of settlement determined based on the surface surveys should be considered as tentative and requiring verification by further research.

\section{Przeworsk culture settlement at Bejsce}

Settlement or possibly even complex of settlements of the Przeworsk culture in Bejsce covered the southern part of the surveyed terrain form. It is worth mentioning that within the area covered by the remains of the activity dated to the Iron Age, also older materials were discovered. The range of the site was broadly established on the basis of the spread of surface finds of the pottery fragments. It is not possible to clearly delimit the full range of settlement activity in the analysed horizon also because of the methodological limitations of the field walking surveys. It is however possible, thanks to the precise measurement of the point location of finds to outline general zones of settlement activity in the subsequent chronological horizons.

During the field walking survey prehistoric materials that should be dated broadly to the Neolith and Bronze Age were also recorded. Single graphite-pottery fragments attributed to the La Tène culture, most probably dated to the middle La Tène period were found as well (Fig. 3: 1,2). Single traces of settlement activity from the mentioned period of time occurred dispersed loosely on the terrain form.

The most numerous were the pottery fragments attributed to the Przeworsk culture. The earliest materials of mentioned culture are dated to the Late Pre-Roman period, most probably to the middle of that phase, as evidenced by individual finds representing i.e. older pottery style of the Przeworsk culture, characterised by the thickened and facetted rims (Fig. 3: 3-6). 

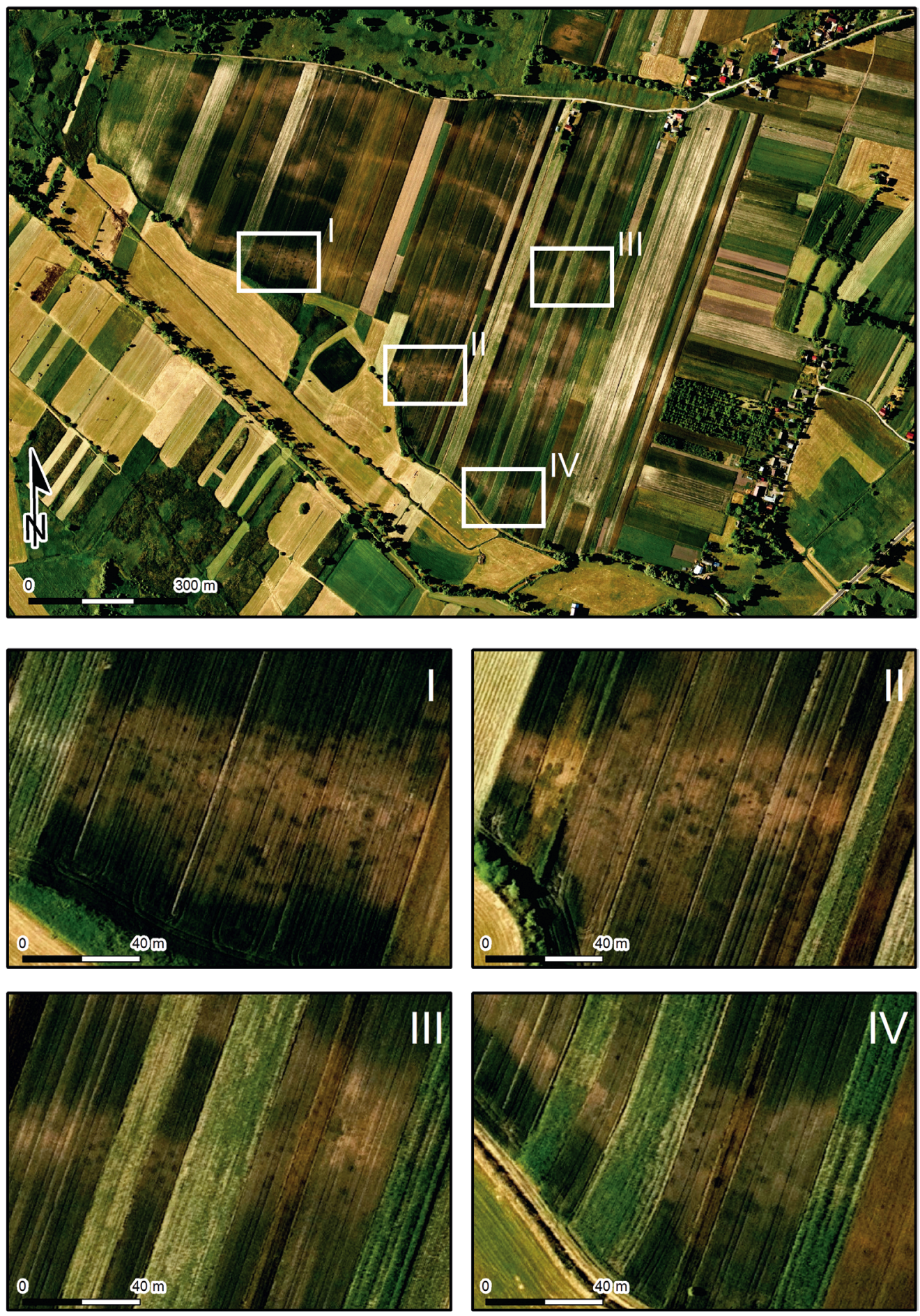

Fig. 2. Examples of vegetation anomalies recorded in the settlement complex at Bejsce 


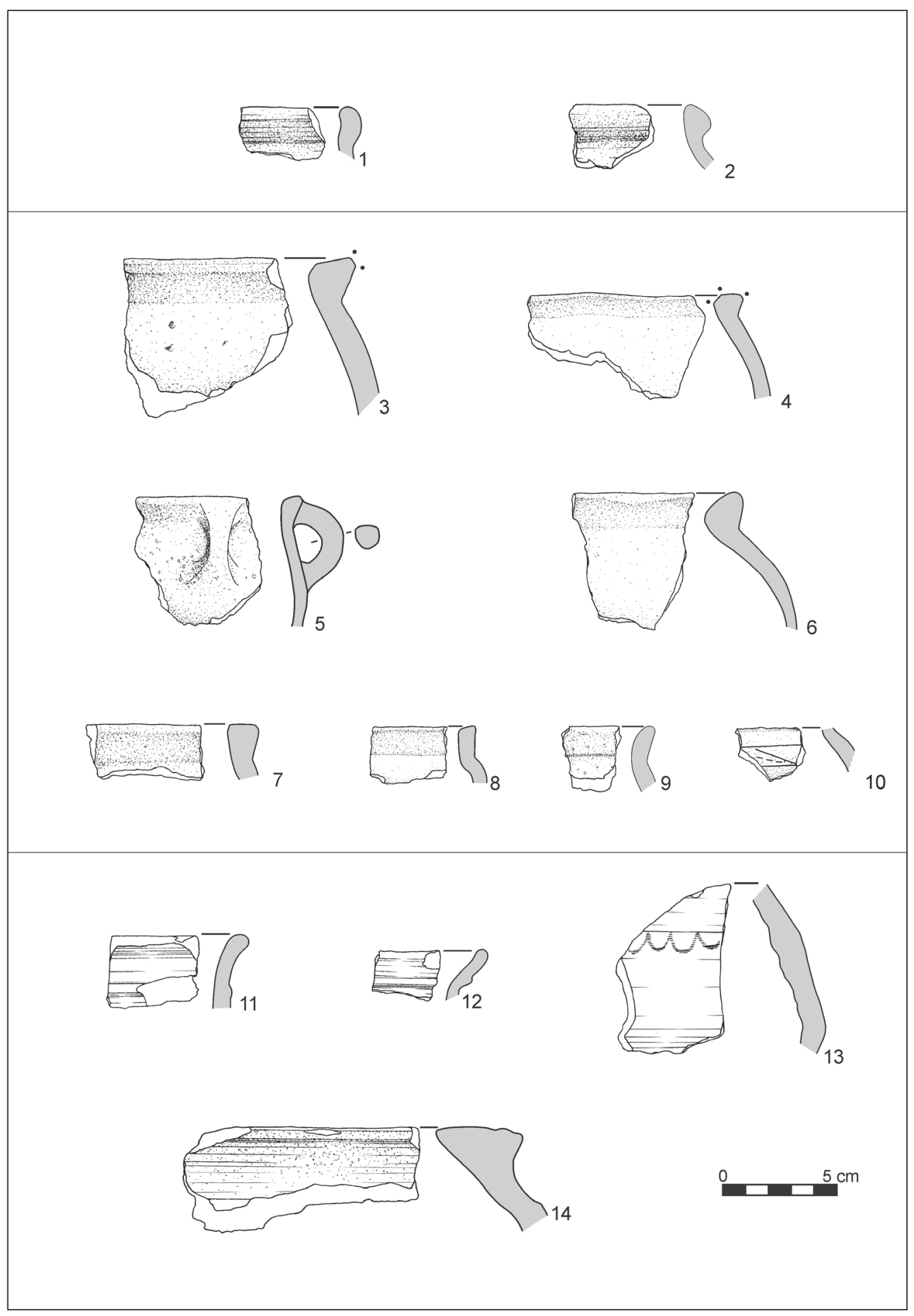

Fig. 3. Selection of finds from the area of the Bejsce settlement; 1-14 - clay 
To the same period of time should be dated the fragment with the incised geometric ornament contained in the narrow ornamentation strip (Fig. 3: 10). Equally numerous were the fragments dated to the Early Roman period (Fig. 3: 7-9). Both mentioned groups of materials were found in the eastern part of the site (cf. Fig. 1).

Different spatial distribution was noticed according to the materials dated broadly to the phase $\mathrm{C}$ and D of the Roman period and Migration period, which occurred mostly in central and the western part of the site. Most numerous are the wheel-made pottery fragments. Within such dated fragments were typical for this period of time fine, grey pottery sherds, including ornamented with burnished motifs as well as fragments of storage vessels in Krausengefasse type (Fig. 3: 11-14).

\section{Przeworsk culture cemetery at Bejsce ${ }^{4}$}

Approximately $300 \mathrm{~m}$ to the north from the boundary of the zone where artefacts linked with the part of the Przeworsk culture settlement used in the Late Pre-Roman and Early Roman period occurred in a compact manner, remains of a badly damaged necropolis from the same period were found (Fig. 1). Burials damaged by agricultural activity manifested themselves at the surface of the ploughed field as darker marks, containing single fragments of pottery (often bearing traces of exposure to high temperature), tiny cremated human bones, and a few artefacts originally belonging to grave furnishings (Fig. 4). Among the latter, it is worth mentioning two spindle-whorls and fragments of iron knives, including a well-preserved example with the hilt distinguished from both sides, which bore traces of fire patina (Fig. 4: 7-9). The mentioned darker areas were shallow, and were remains of upper parts of cremation burials which had been ploughed through, and then turned over and moved by the plough. The burials themselves can be expected to be found close to the dark marks. In the case of one grave, situated immediately by a deep balk, ploughing uncovered a part of its fill in situ. To prevent the ongoing destruction of the grave (designated as grave 1), a decision was made to perform rescue excavations in this place.

It is also worth noting that a Roman denarius has been found within the necropolis (Fig. 5; table 1). The coin represents a type issued in 101-102 AD during the reign of Emperor Trajan (RIC II 58). Roman coins are not frequent finds in Przeworsk culture cemeteries (Kaczanowski, Poleski 1985, 135). Interestingly, a Trajan denarius of the same type was discovered in the Kawczyce necropolis, Comm. Busko Zdrój (Kaczanowski, Poleski 1985, 125, fig. 12). As is the case with the coin from Bejsce, the denarius from Kawczyce does not have a precise context - it was discovered in a secondary context in a modern period trench (Kaczanowski, Poleski 1985, 117).

Based on the distribution of surface finds, the size of the newly discovered cemetery can be estimated as approx. 0.5 ha, however it must be emphasised that it is preliminary observation. The necropolis most likely occupies one of the culminations of the discussed land form. A geophysical survey ${ }^{5}$ has also been carried out in the necropolis, although its interpretation will only become possible after opening excavations.

4 Before printing of this article, and after its submission for publication, a larger scale sondages were conducted on the site, the effects of which will be presented in subsequent texts.

5 We would like to heartily thank Marcin M. Przybyła and his team for performing the geomagnetic prospection on the site. 


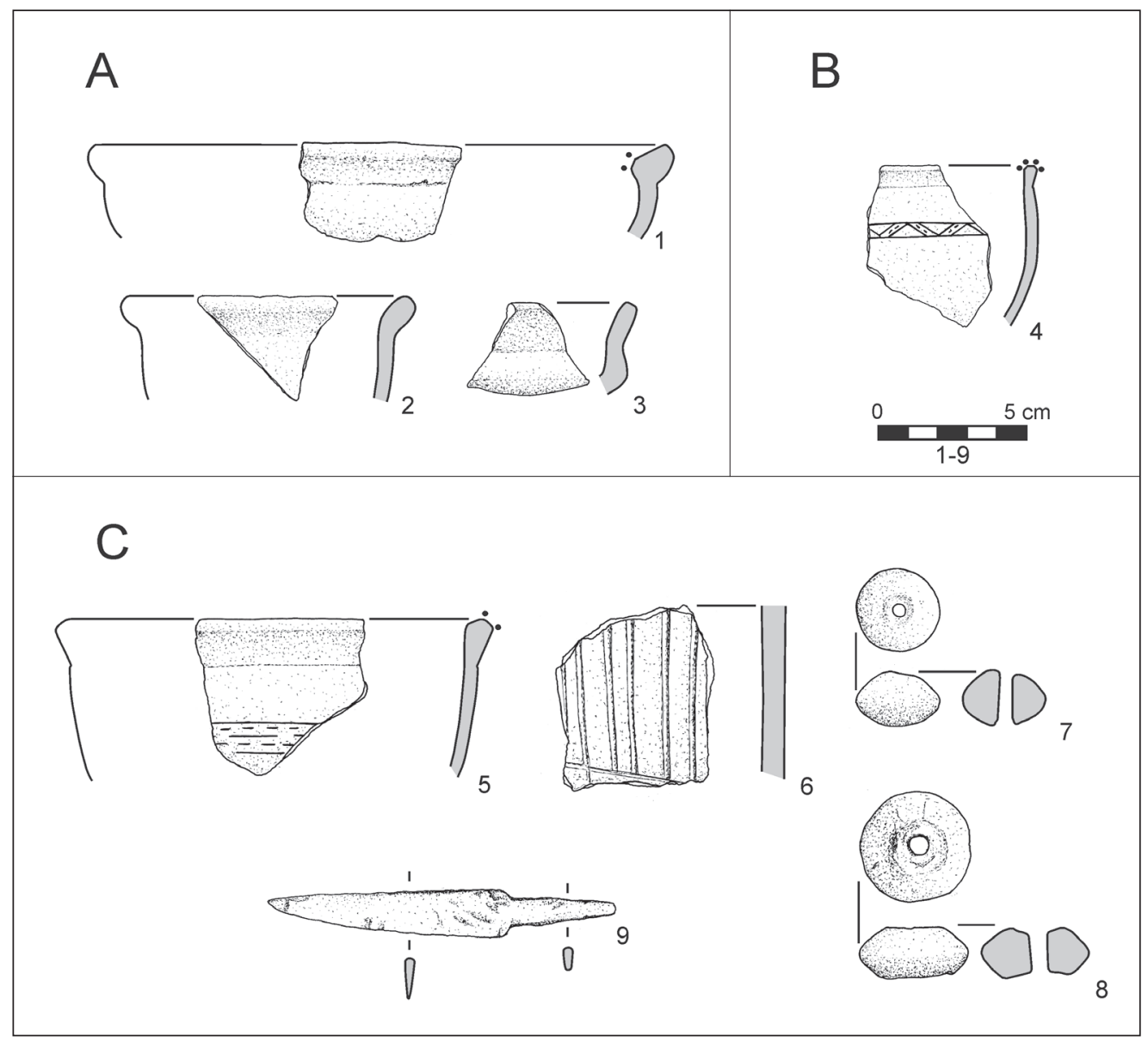

Fig. 4. Selection of finds from the area of the Bejsce cemetery; A - cluster 2, B - vicinity of cluster 5, $\mathrm{C}$ - stray finds (outside clusters); 1-8 - clay, 9 - iron

\section{Grave 1}

\section{Description of the grave}

Cremation in pit. Its upper part has been damaged in the western part due to the deepening of the balk. The grave cut, revealed at a depth of $20 \mathrm{~cm}$ beneath the ground surface, was of irregular, elongated shape, $100 \times 45 \mathrm{~cm}$ in size. The upper part of the grave produced fragments of pottery, including sherds bearing traces of exposure to high temperature. The fill contained fragments of cremated human bones and tiny pieces of charcoal. The grave pit was throughshaped in cross-section, and its preserved thickness was approx. $20 \mathrm{~cm}$ (Fig. 6).

In the immediate vicinity of the grave, a shallow, dark mark containing cremated human bones and potsherds was identified at the ground surface. It was designated as cluster 1, and should most likely be interpreted as remains of the upper part of grave 1, damaged and moved by ploughing. This is evidenced by the fact that conjoining sherds were found in the in situ part of grave 1 and in cluster 1 . 


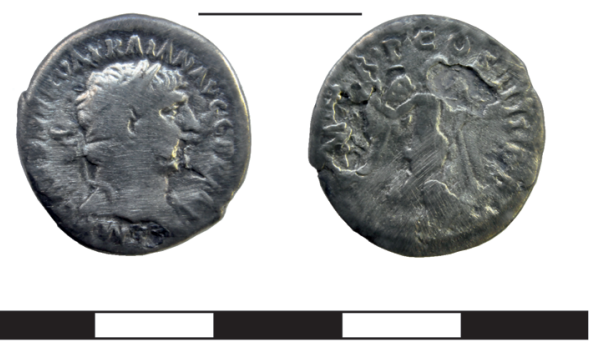

Fig. 5. Denarius found on the surface of the Bejsce cemetery

Table 1. Description of the denarius discovered in the Bejsce necropolis

Location: Bejsce, Bejsce Commune, Kazimierza Wielka District, Świętokrzyskie Voivodeship

Roman Empire, Traianus (138-161), Rome, AD 101-102, AR, denarius

Obverse: Bust of Trajan, laureate, r.; on 1.: IMP CAES NERVA TRA; on r.: IAN AVG GERM

Reverse: Victory, naked to waist, standing front, head 1., holding up wreath in r. hand and palm in 1. on 1.: P M TR P; on r.: COS IIII P P

wt: $2.50 \mathrm{~g}$; dia.: $19 \mathrm{~mm}$; axis - vi

RIC II 58

Inventory (Fig. 7): 6

1. Catchplate fragment from an iron brooch of Late La Tène construction, of undetermined type.

2. Fragment of a vase with a thickened, faceted rim, with a narrow band of decoration in the form of shallow, double incised zigzag in the upper body (type $2 \mathrm{~b}$ in $\mathrm{K}$. Czarnecka's classification ${ }^{7}$ ); external and internal surfaces black, smoothened; h.: $13.5 \mathrm{~cm}$; rim diam.: $19 \mathrm{~cm}$; body diam.: $20 \mathrm{~cm}$; base diam.: $10 \mathrm{~cm}$.

3. Fragment of a bowl of Dąbrowska type II.1-3, with a slightly thickened rim; external and internal surfaces orange-grey, with distinct traces of exposure to high temperature, rim diam.: $23 \mathrm{~cm}$.

4. Fragment of a bowl of Dąbrowska type II.4; external and internal surfaces of non-uniform, orange-brown colour; rim diam.: $17 \mathrm{~cm}$.

5. Fragment of a pot of Dąbrowska type VI.1, with thickened rim, with faceting poorly marked and visible only on the inner side; the body has been coarsened by application of clay; external and internal surfaces orange; h.: $16.5 \mathrm{~cm}$; rim diam.: $17 \mathrm{~cm}$; body diam.: $19.5 \mathrm{~cm}$.

6 Inventory numbers correspond with numbers in Fig. 7. The same system is also used further in the text, with the running numbers of particular artefacts given in brackets.

7 Cf. Czarnecka 2007, 100. 

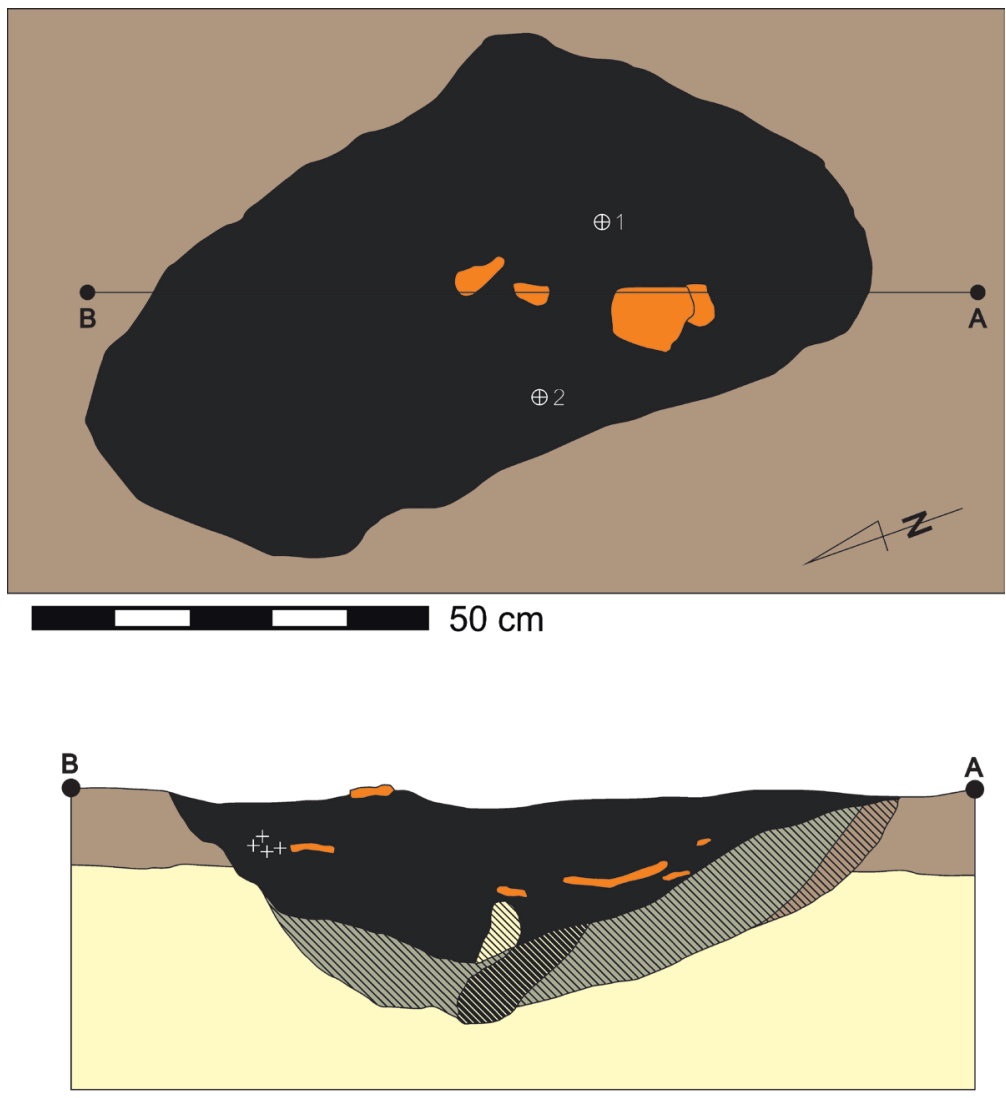

$50 \mathrm{~cm}$

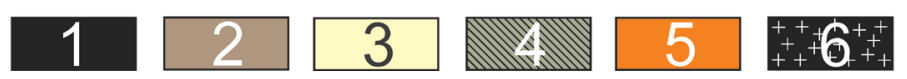

Fig. 6. Plan and cross-section of grave 1 at Bejsce; 1 - layer of dark-brown soil saturated with charcoal, 2 - layer of buried humus, of brown colour, 3 - layer of sandy soil of yellow-orange colour, 4 - mixed layer, 5 - pottery, 6 - tiny fragments of cremated human bones

6. Rim sherd from a vessel of Dąbrowska type VI.1, with thickened rim, with faceting poorly marked; external and internal surfaces orange; rim diam.: $22.5 \mathrm{~cm}$.

7. Rim sherd from a vessel of Dąbrowska type VI.1 (?), with thickened rim, with faceting poorly marked; external and internal surfaces orange; rim diam.: $13 \mathrm{~cm}$.

8. Rim sherd from a cup of Dąbrowska type I, with slightly thickened rim; external and internal surfaces black.

9. Rim sherd from a vessel of undetermined type, with a handle base preserved; the rim is slightly thickened with poorly marked faceting, probably part of the vessel (7).

10. Base of a vessel of undetermined type, external and internal surfaces black and smooth, probably part of the vessel (8); base diam.: $6 \mathrm{~cm}$.

11. Base sherd from a vessel of undetermined type, external and internal surfaces orange, base diam.: $9 \mathrm{~cm}$. 
12. Base sherd from a vessel of undetermined type, external surface orange with browngrey stains, internal surface grey, base diam.: approx. $12 \mathrm{~cm}$.

13. Fragment of an oval-sectioned handle, orange.

14. Fragments of vessels of undetermined types.

Results of anthropological analysis (the analysis was performed by dr hab. Anita Szczepanek): ${ }^{8}$

The bones discovered in grave 1 weighed $300 \mathrm{~g}$. They were strongly and unevenly burned, of crème and crème-grey colour. The bones most likely belonged to a woman (??) aged Adultus/ Maturus (30-40 years). The anthropological analysis also encompassed the bones discovered within cluster 1 (weighing $18 \mathrm{~g}$ ). The results indicate that it is possible that they belong to the same person whose remains were placed to grave 1 .

\section{Analysis of the archaeological material}

The original composition of the inventory of grave 1 cannot be reconstructed due to considerable damage caused by agricultural activity. Furthermore, one cannot rule out that the grave was partly looted by metal detectorists, whose years-long illegal activity in the area of the settlement and cemetery at Bejsce is confirmed by accounts of local residents. In the absence of precise chronological indicators such as well-preserved metal artefacts, the dating of the assemblage must rely primarily on the analysis of the ceramic objects. They represent a set of forms typical of the Przeworsk culture, including carefully made vessels with smooth, most often black surfaces, sometimes decorated, as well as thick-walled pottery with less carefully worked surfaces, sometimes coarsened.

Among the first of these two groups one should place, among other forms, the ornamented vase (2) distinguished by a highly-placed shoulder. It corresponds to bowls of type IIA.V.4.2 in P. Poleska's classification (Poleska 2006, 92-93), although admittedly it is more squat than most of the vessels included in this type. In terms of proportions it is closer to vases of Dąbrowska type IV (Dąbrowska 1997, 103), widespread in the Late Pre-Roman Period, which is equivalent to IIA.VI.1 in Poleska's classification (Poleska 2006, 95-97). However, unlike the latter, the neck of the vessel in question is not separated. Vessels similar to the one from Bejsce occur occasionally in Przeworsk culture and Tyniec group sites, with closer analogies known from settlements from the Kraków region: Kraków-Pleszów, st. 17 (Poleska 2006, pl. 80: 1), Kraków-Wyciąże, st. 5 (Poleska 2006, pl. 223:8), and Podłęże (Woźniak 1990, pl. XXII: p). Furthermore, similar vessels are known from the Karczewiec necropolis (Dąbrowska 1973, pl. XXIV: 14; XLVII: 7; XLVIII: 10). High shoulders are considered a late tendency in the Przeworsk culture pottery of the Late Pre-Roman Period (Dąbrowska 1988, 14-62; ${ }^{9}$ Poleska 2006, 93 ) - in the Early Roman period it was to become an integral element of the strongly profiled style predominant at that time. It should be noted that the discussed vessel from grave 1 is the only one to have a thickened and carefully faceted rim and to feature incised geometric decoration in the upper part of the body, in the form of a zigzag framed by double line (type $2 b$ acc. to Czarnecka 2007, 100, fig. 4).

\footnotetext{
8 We would like to express here our gratitude for performing the analysis.

9 See chronological position of vessels with highly placed maximum body diameter (attributes 59 and 61) (Dąbrowska 1988, pl. IV:59, 61, list 13)
} 


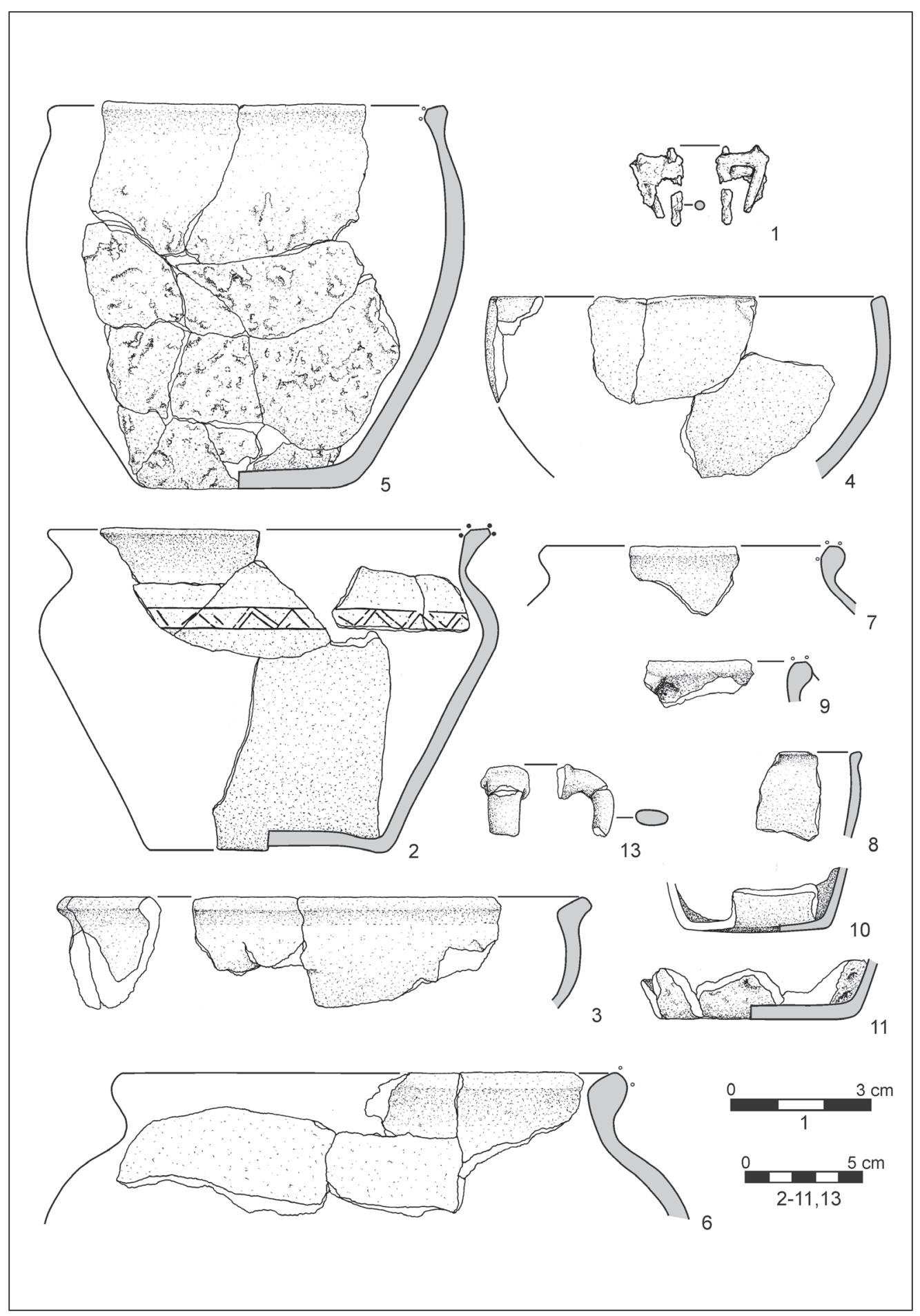

Fig. 7. Inventory of grave 1 at Bejsce, 1 - iron, 2-13 - clay 
Another vessel from the group distinguished by careful surface treatment is the fragmentarily preserved cup $(8 ; 10)$ representing Dąbrowska type I (Dąbrowska 1997, 102), which corresponds to the type IIA.IV in Poleska's classification (Poleska 2006, 84-89). Such vessels are frequent finds in settlement and sepulchral sites of the Przeworsk culture, and are not precise chronological indicators.

Grave 1 contained fragments of two bowls, also representing pottery with smooth surfaces. The first one (3) is an S-shaped bowl with a thickened, everted rim. In the absence of a typologically distinctive lower part of the body, it can only broadly be assigned to Dąbrowska type II.1-3 (Dąbrowska 1997, 102). The other vessel is a hemispherical bowl with an undistinguished rim (4), which can be classed as Dąbrowska type II.4 (Dąbrowska 1997, 102) or Poleska type IIA.V.5.2 (Poleska 2006, 94). Both the bowls from grave 1 are long-lasting forms, widespread in Przeworsk culture assemblages in the Late Pre-Roman Period, and also in the early stages of the Early Roman period (bowls of Dąbrowska type II.4). Thus, they cannot be regarded as precise chronological indicators.

The remaining three vessels from grave 1 at Bejsce belong to pottery with unburnished surfaces. The first one is a squatty pot of Dąbrowska type VI.1 (Dąbrowska 1997, 103), with thickened rim bevelled from the inside (5). The body has been coarsened by applying very plastic clay. The remaining two vessels $(6,7)$ probably also represent squat forms with rounded bodies, although their necks are much more narrowed than in the case of the vessel (5). Both have thickened rims, which are additionally formed in a manner similar to faceting, although without sharp borders between the facets. A tiny rim sherd with a vestigially preserved handle base (9) most likely belongs to one of the vessels discussed here (7).

Only one metal artefact was found in grave 1, namely a fragment of a catchplate from an iron brooch of undetermined type (1). The brooch was of undoubtedly late La Tène construction, hence its chronological position can broadly be determined within phases A2-A3 of the Przeworsk culture development.

Summing up, one has to conclude that the observed stylistic tendencies, above all the presence of the vase (2) with a highly-placed, sharply profiled shoulder, argue for dating grave 1 from Bejsce to the late section of the Late Pre-Roman Period, i.e. to phase A3. At the same time, however, it should be emphasised that analogical finds are also known from the younger section of phase A2, from phase A2/A3, as well as from the earliest section of the Early Roman period. The catchplate fragment from a late La Tène brooch of undetermined type (1) discovered in grave 1 should be linked with the same, relatively broad, timespan.

\section{Recapitulation}

The recently discovered cemetery at Bejsce adds to the list of known traces of Przeworsk culture occupation between the Nida and Nidzica rivers in the Late Pre-Roman and Early Roman period, and is another necropolis from that period known from the loess areas in western Lesser Poland. Until relatively recently, sepulchral sites were not particularly well-represented in this area. Therefore, it was repeatedly suggested in the literature that this situation may have stemmed from longer survival of certain sepulchral traditions linked with Celtic communities, which were an important component of the Tyniec group developing in this area (Kaczanowski, Madyda-Legutko, Poleski 1984, 116-117; Dobrzańska 1995, 37, with further literature). In recent years, however, one could observe a significant growth in the number of Przeworsk culture cemeteries from the Late Pre-Roman and Early Roman period, identified by surface surveys or excavations. One can 
mention here for example the excavated necropolises at Michałowice, Comm. Czarnocin (Zagórska-Telega, Pikulski, Szczepanek 2011; Zagórska-Telega, Pikulski, Bulas 2012), Morawianki, Comm. Bejsce, ${ }^{10}$ and Kazimierza Mała, Comm. Kazimierza Mała. ${ }^{11}$ This suggests that the previous views on the issue stemmed in most part from the state of research on Przeworsk culture sites, and that the network of Przeworsk culture cemeteries from the discussed period was most likely relatively dense and corresponded to a significant extent with the network of settlements.

The cemetery at Bejsce is part of a complex which also includes a settlement from the same period and situated within the same landform, which opens up an opportunity for tracing spatial relationships between the two sites. In addition, the mentioned complex appears to be of significant importance for studies on the Przeworsk culture settlement network in the microregion. The preliminary assessment of the size of the site - or sites - from the Late Pre-Roman Period and Early Roman period suggests that this was one of the largest settlements in the area. However, this hypothesis needs to be verified by further field research.

\section{Nowo odkryta osada i cmentarzysko kultury przeworskiej z młodszego okresu przedrzymskiego i rzymskiego w Bejscach, pow. Kazimierza Wielka - wstępne wyniki badań powierzchniowych}

Artykuł prezentuje wstępne wyniki badań powierzchniowych prowadzonych pod kierunkiem autorów wiosną 2019 roku na terenie wielokulturowego kompleksu stanowisk obejmujących wyniesienie położone w południowo-zachodniej części miejscowości Bejsce, pow. Kazimierza Wielka. Wśród odkrytych znalezisk dominowały fragmenty naczyń, które łączyć należy z osadnictwem ludności kultury przeworskiej, datowanym na młodszy okres przedrzymski, okres wpływów rzymskich oraz wczesną fazę okresu wędrówek ludów. Osada lub też kompleks osad ludności kultury przeworskiej położone były w południowej części badanej formy terenowej, podczas gdy w odległości ok. 300 m na północ od granicy osady, odkryto pozostałości silnie niszczonej nekropoli datowanej na młodszy okres przedrzymski oraz wczesny okres wpływów rzymskich. Ze względu na fakt, że w przypadku jednego z pochówków, położonego w obrębie miedzy, w wyniku głębokiej orki doszło do jego znaczącego odsłonięcia, w celu zapobiegnięcia dalszym zniszczeniom zadecydowano o przeprowadzeniu w tym miejscu badań ratowniczych.

\section{References}

Dąbrowska T., 1973 Cmentarzysko kultury przeworskiej w Karczewcu, pow. Węgrów, Materiały Starożytne i Wczesnośredniowieczne, 2, pp. 383-531.

1988 Wczesne fazy kultury przeworskiej. Chronologia, zasięg, powiązania, Warszawa.

1997 Kamieńczyk. Ein Gräberfeld der Przeworsk-Kultur in Ostmasowien, Monumenta Archaeologica Barbarica, 3, Kraków.

Dobrzańska H., 1995 Kultura przeworska na wyżnach lessowych Zachodniej Małopolski w okresie rzymskim - główne problemy badawcze, Sprawozdania Archeologiczne, 47, pp. 33-53.

10 For information about this site we are indebted to Marcin M. Przybyła who carried out the research there.

11 For information about this site we are indebted to Krzysztof Tunia who carried out the research there. 
Gajewski L., Woźniak Z., 2000 Cmentarzysko wczesnoprzeworskie ze Stradowa, pow. Kazimierza Wielka, Sprawozdania Archeologiczne, 52, pp. 231-327.

Godłowski K., 1986 Jakuszowice. Eine Siedlung der Bandkeramik, älteren Bronzezeit, jüngeren vorrömischen Eisenzeit, römischen Kaiserzeit und der frühen Völkerwanderungszeit in Südpolen, Die Kunde N.F., 37, pp. 103-131.

1991 Jakuszowice, a multi-period settlement in southern Poland, Antiquity, 65, pp. 662-675.

Grygiel M., Pikulski J., Trojan M., 2009a Rescue excavations on the Late Roman period settlement on site 3 in Zagórzyce, com. and distr. Kazimierza Wielka, voiv. Świętokrzyskie, Recherches Archéologiques Nouvelle Serie, 1, pp. 277-294.

2009b The research on the multicultural site no. 1 in Zagórzyce, com. and distr. Kazimierza Wielka, voiv. Świętokrzyskie during the years 2003 to 2004, Recherches Archéologiques Nouvelle Serie, 1, pp. 199-275.

Kaczanowski P., Madyda-Legutko R., Poleski J., 1984 Cmentarzysko kultury przeworskiej w Górce Stogniewskiej koło Proszowic, Sprawozdania Archeologiczne, 36, pp. 84-121.

Kondracki J., 1965 Geografia fizyczna Polski, Warszawa.

Kontny B., Rudnicki M., 2002 Ostrogi z Pełczysk, pow. pińczowski. Nowe oblicze stanowiska z okresu lateńskiego i okresu wpływów rzymskich, Światowit. Fascykuł B, 4, pp. 145-157.

Kruk J., 1980 Gospodarka w Polsce poludniowo-wschodniej w V-III tysiacleciu p.n.e., Wrocław.

Kulczycka-Leciejewiczowa A., 1987 Pierwsze wspólnoty kultury ceramiki wstęgowej rytej na ziemiach polskich, Archeologia Polski, 32, pp. 293-348.

Poleska P., 2006 Celtycki mikroregion osadniczy w rejonie podkrakowskim, Biblioteka Muzeum Archeologicznego w Krakowie, 2, Kraków.

Rudnicki M., 1996 The Celtic settlement at Petczyska near Złota, (in:) Z. Woźniak (ed.), Kontakte längs der Bernsteinstrasse (zwischen Caput Adriae und den Ostseegebieten) in der Zeit um Christi Geburt. Materialien des Symposiums, Kraków, 26.-29. April 1995, Kraków, pp. 243-256.

Woźniak Z., 1990 Osada grupy tynieckiej w Podtężu, woj. krakowskie, Wrocław.

Zagórska-Telega J., Pikulski J., Bulas J., 2012 Excavations of multicultural site 1 at Michałowice, Czarnocin commune, Świętokrzyskie province, season 2011, Recherches Archéologiques Nouvelle Serie, 4, pp. 135-160.

Zagórska-Telega J., Pikulski J., Szczepanek A., 2011 Excavations of multicultural site 1 at Michałowice, Czarnocin commune, Świętokrzyskie province, in the years 2008-2010, Recherches Archéologiques Nouvelle Serie, 3, pp. 195-225. 
ISSN 0137-3285 